\title{
Combined Effects of Deformation and Undercooling on Isothermal Bainitic Transformation in an Fe-C-Mn-Si Alloy
}

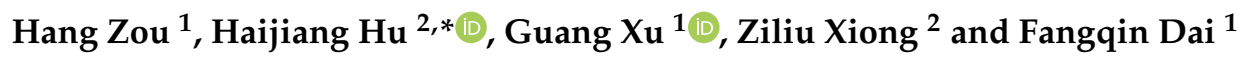 \\ 1 The State Key Laboratory of Refractories and Metallurgy, Wuhan University of Science and Technology, \\ Wuhan 430081, China; zou_hang_happy@126.com (H.Z.); xuguang@wust.edu.cn (G.X.); \\ daifangqin@wust.edu.cn (F.D.) \\ 2 HBIS Group Technology Research Institute, Hebei Iron and Steel Group Co., Ltd., Shijiazhuang 05000, China; \\ xiongziliu@hbisco.com \\ * Correspondence: huhaijiang@wust.edu.cn; Tel.: + 86-027-6886-2813
}

Received: 11 January 2019; Accepted: 24 January 2019; Published: 27 January 2019

\begin{abstract}
Both ausforming and transformation temperature affect the successive bainitic transformation and microstructure. The individual influence of each case is clear, whereas the combined effects are still unknown. Thermomechanical simulation and metallography were used to investigate the combined effects of ausforming and transformation temperature on bainitic transformation and microstructure. The kinetics of isothermal bainitic transformation in non-deformed and deformed materials was analyzed. A lower transformation temperature can lead to more bainite formation without deformation. However, ausforming with small strains can partially compensate for the decrease of bainite amount caused by the decreased undercooling. The larger the applied strain is, the smaller the difference between the final amounts of bainite with different undercooling. Ausforming at a relatively higher temperature is more favorable to the acceleration of subsequent isothermal bainitic transformation. The results in the present work provide reference for optimizing the fabrication technology of medium-carbon nanobainite steels.
\end{abstract}

Keywords: ausforming; bainitic transformation; microstructure; transformation temperature

\section{Introduction}

For the past decade, advanced high strength bainitic steels have been widely investigated as a third generation automotive material. High carbon nanobainite steels with a microstructure of lath-like nanoscale bainite and film-like retained austenite (RA) exhibit a tensile strength of $\sim 2.5 \mathrm{GPa}$ and fracture toughness greater than $30 \mathrm{MP} \cdot \mathrm{m}^{1 / 2}$ [1-3]. Unfortunately, the very long duration of low-temperature isothermal transformation limits its commercial application. Aluminum and cobalt are added into high-carbon nanobainite steels to reduce the heat treatment time [4-6], and the time can be shortened from several days to $\sim 10 \mathrm{~h}$ despite being impractical for industry. Low carbon bainitic steels can be designed to shorten the incubation period and improve weldability and impact toughness [7]. However, decreasing carbon concentration causes a considerable increase of martensite start temperature $(M s)$, making austempering proceed at relative high temperatures, and thereby coarsening bainite laths. Therefore, a medium-carbon Si-Mn-rich alloy could be a desired alternative to produce high strength nano-structure bainite steel. Actually, many works have already been conducted on transformation, microstructure and property of medium-carbon bainite steels (MCBS) [8-12].

More volume fraction of nanobainite and a short transformation time are two important targets in the preparation of high strength MCBS. Bainitic transformation has a characteristic of incomplete transformation (ICT) [13], in which reaction stops prematurely before the equilibrium amount is 
attained. The nature of ICT phenomenon could be explained by the concept of the $T_{0}$ curve $[14,15]$, which places strict limits on the maximum fraction of transformation that can be achieved theoretically. In fact, both theoretical calculation and experimental results have proven that a lower transformation temperature can lead to an increase of bainite formation [16-18]. However, the time for transformation could be prolonged below the nose temperature of the time-temperature-transformation (TTT) curve, which is inversely correlated to the expectation. In the author's previous works [19,20], an ausforming with small strain at low temperatures could not only accelerate the kinetics of bainitic transformation, but also increase the final volume fraction of bainite. Gong et al. [21,22] also claimed that the dislocation structure introduced in austenite by low temperature ausforming is found to assist bainite transformation with strong variant selection where partial dislocations introduced by ausforming play an important role for bainite transformation. Yang et al. [23] also claimed that a two-steps process can be used to shorten the transformation time from over $60 \mathrm{~h}$ to nearly $25 \mathrm{~h}$. He et al. [24] reported that the kinetics of bainitic transformation depends on the competition between the increase in nucleation rate and the decrease in average volume of bainite sheaf after deformation. The increase in nucleation rate overcomes the decrease in the average volume of bainite sheaf, resulting in the increase in transformation velocity and volume fraction after small deformation. In this way, a low-temperature ausforming could be utilized to promote transformation when producing low-temperature carbide-free bainitic steels by rolling processing technology. However, considering that the resistance force can be enhanced by the decrease of deformation temperature, the ausforming conditions should be optimized.

In the present work, the combined effects of ausforming and transformation temperature on bainitic transformation and microstructure were investigated by thermomechanical simulation and metallography. The results are significant in optimizing the preparation technology of medium-carbon nanobainite steels.

\section{Materials and Methods}

The chemical composition of the tested steel was Fe-0.40C-2.00Si-2.80Mn-0.04Al (wt. \%). The material was refined in a vacuum induction furnace and casted into a $50 \mathrm{~kg}$ ingot followed by hot rolled to a slab of $14 \mathrm{~mm}$ thickness. Samples for simulation tests were machined to a cylinder of $8.0 \mathrm{~mm}$ diameter and $12 \mathrm{~mm}$ height. The top and bottom surfaces of samples were conventionally polished to keep the measurement face level and minimize the effect of surface roughness. Thermomechanical simulation tests were conducted on a Gleeble-3500 thermal simulator (Dynamic Systems Inc., New York, NY, USA) according to the processing schedules shown in Figure 1. Austenitizing temperature has an important effect on a successive kinetics of bainite formation. In order to avoid the coarsening of austenite grain, a low austenitizing temperature was selected. All specimens were austenized at $900{ }^{\circ} \mathrm{C}$ for $15 \mathrm{~min}$ and then cooled to 300 and $350{ }^{\circ} \mathrm{C}$, respectively. A cooling rate of $10^{\circ} \mathrm{C} \cdot \mathrm{s}^{-1}$ was utilized to avoid ferrite and pearlite transformation. After compression deformation at respective temperatures with a strain of $0.1,0.2$ and 0.3 (strain rate is $1 \mathrm{~s}^{-1}$ ), respectively, all the samples were isothermally held for $90 \mathrm{~min}$ for bainitic transformation. The external compressive stress was kept to a very small value during isothermal holding so that the influence of external compressive stress could be ignored. After isothermal holding, the specimens were air-cooled to ambient temperature. Meanwhile, two non-deformed specimens were tested with the same heating and holding routes. To obtain nano-structured lath bainite, the transformation temperature should be design as low as possible between Ms and bainite starting temperature $(B s)$. The time temperature transformation (TTT) diagrams of the steel was calculated by MUCG83 (Modified version of MUCG73 and MUCG46, Cambridge, UK) [25,26], as shown in Figure 2. The $B s$ and $M s$ are 423 and $256{ }^{\circ} \mathrm{C}$, respectively, indicating that bainite could be formed during austempering at 300 and $350{ }^{\circ} \mathrm{C}$. The variation of transformation temperature was attempted to cause a difference in undercooling. 


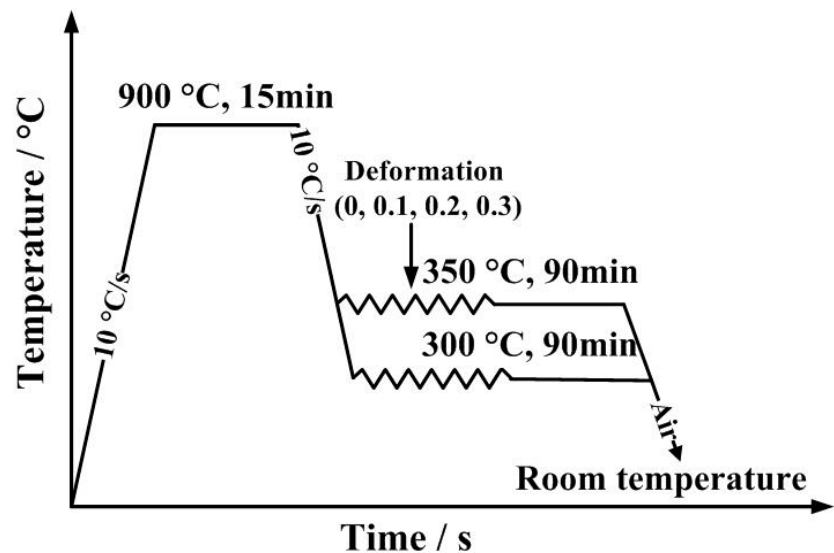

Figure 1. Experiment procedures.

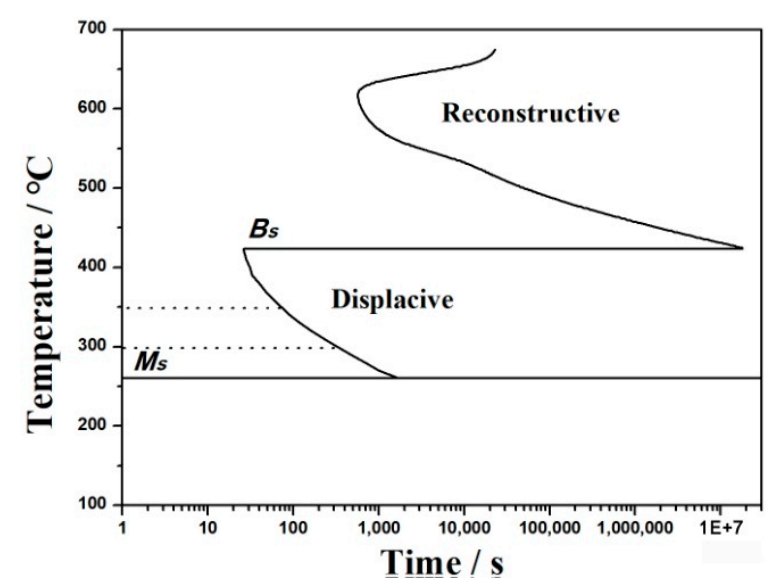

Figure 2. The time temperature transformation diagrams of tested steel.

In all cases, the dilatation data during the whole process were recorded by a laser dilatometer. A Nova400Nano field emission scanning electron microscope (SEM, FEI Co., Hillsboro, OR, USA) was used to examine microstructure of all specimens with an acceleration voltage of $20 \mathrm{kV}$. The metallographical specimens were etched with $4 \%$ nital. In addition, the fine microstructure was observed using a JEM-2100F transmission electron microscope (TEM, JEOL, Ltd., Tokyo, Japan). The distribution, size (width), morphology and amount of bainite were analyzed based on above metallographical results.

\section{Results}

\subsection{Microstructure}

From the SEM micrographs in Figure 3, lath-like bainite (B) can be observed in the microstructure of all cases including non-deformed and deformed samples. Film-like and blocky retained austenite (RA) is shown by a higher solution image in Figure 3a. In addition, all samples contain martensite (M) pointed by arrows in Figure 3a,e. Generally, the microstructure of each case consists of B, RA and $\mathrm{M}$, while the amount of each phase is significantly different. For the two non-deformed samples (Figure 3a,e), the amount of bainitic transformation presents a distinct decrease when the transformation temperature increases by $50{ }^{\circ} \mathrm{C}$. In addition, the bainite sheave tends to be finer at a transformation temperature of $300^{\circ} \mathrm{C}$. However, it is hard to distinguish from Figure $3 \mathrm{~b}, \mathrm{f}$ which one has more bainite when the steel is applied to a strain of 0.1 . The above situation almost has no change after increasing the strain to 0.2 and 0.3, as shown in Figure 3c,g, Figure 3d,h. Finally, it can be observed that large blocky $\mathrm{M}$ in non-deformed samples is eliminated by deformation. A broken 
morphology of microstructure presents when the steel is ausformed at 300 and $350{ }^{\circ} \mathrm{C}$ followed by a subsequent isothermal holding for $90 \mathrm{~min}$.
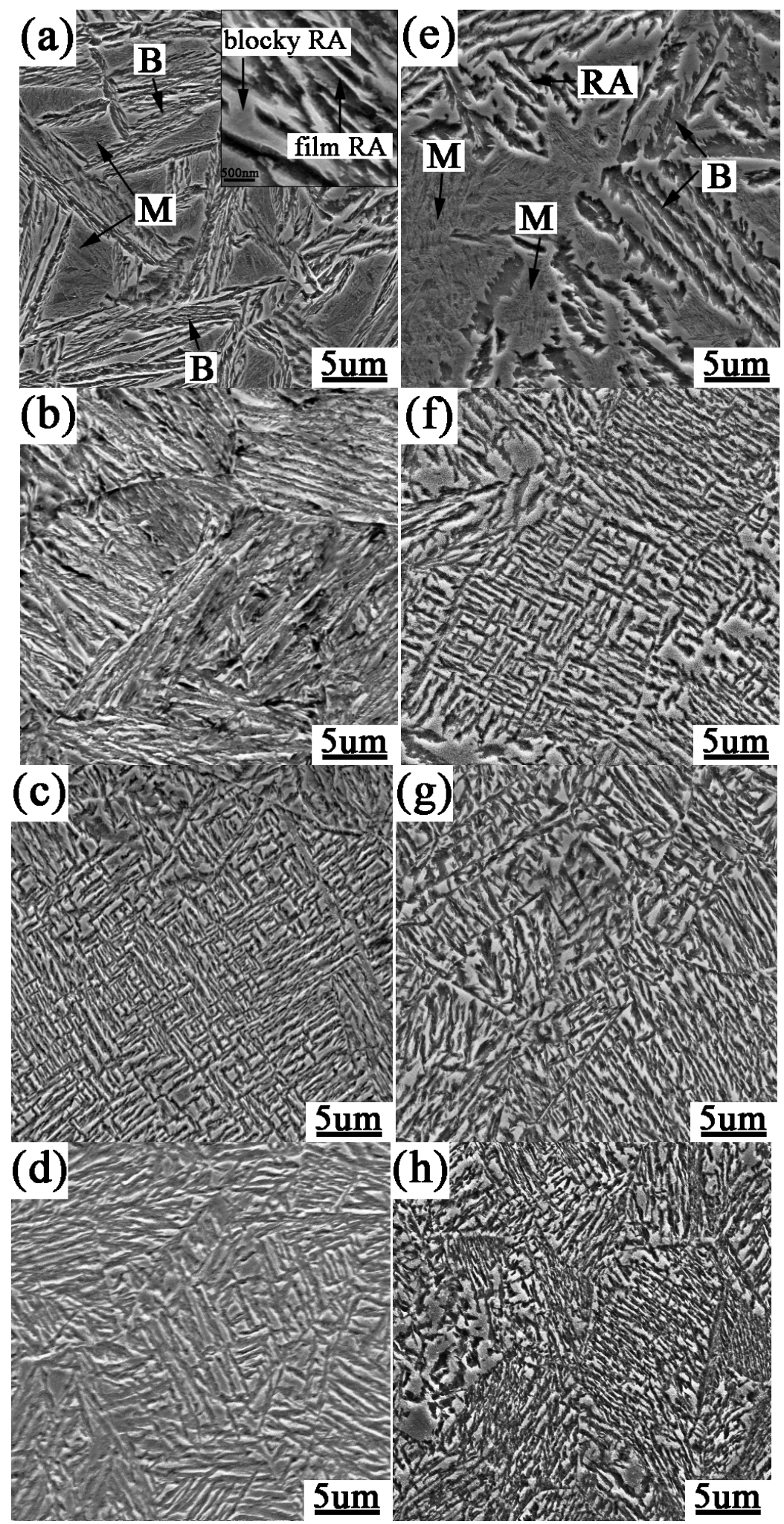

Figure 3. SEM micrographs of samples with different ausforming conditions: (a) without deformation, $300{ }^{\circ} \mathrm{C}$; (b) $0.1,300{ }^{\circ} \mathrm{C}$; (c) $0.2,300{ }^{\circ} \mathrm{C}$; (d) $0.3,300{ }^{\circ} \mathrm{C}$; (e) without deformation, $350{ }^{\circ} \mathrm{C}$; (f) $0.1,350{ }^{\circ} \mathrm{C}$; (g) $0.2,3500^{\circ} \mathrm{C}$; (h) $0.3,350^{\circ} \mathrm{C}$. 
To clarify the effect of ausforming on microstructure in tested steel, TEM micrographs of non-deformed and 30\% strain deformed samples transformed at $300{ }^{\circ} \mathrm{C}$ are presented in Figure 4 . Film-like RA $(\gamma)$ distributes between two bainite laths $(\alpha)$, as shown in Figure $4 \mathrm{a}$,c. The thickness $t$ of lath-like phases could be determined using the mean linear intercept $L=\pi t / 2$ method in a direction normal to the plates [4]. Based on multiple calculations, the average thicknesses of bainite laths in non-deformed and deformed samples were calculated as $\sim 385 \mathrm{~nm}$ and $\sim 198 \mathrm{~nm}$, respectively. This indicates that ausforming can significantly refine bainitic microstructure, which is beneficial for strength. Meanwhile, blocky RAs also can be refined by deformation, as shown in Figure $4 b$,d.

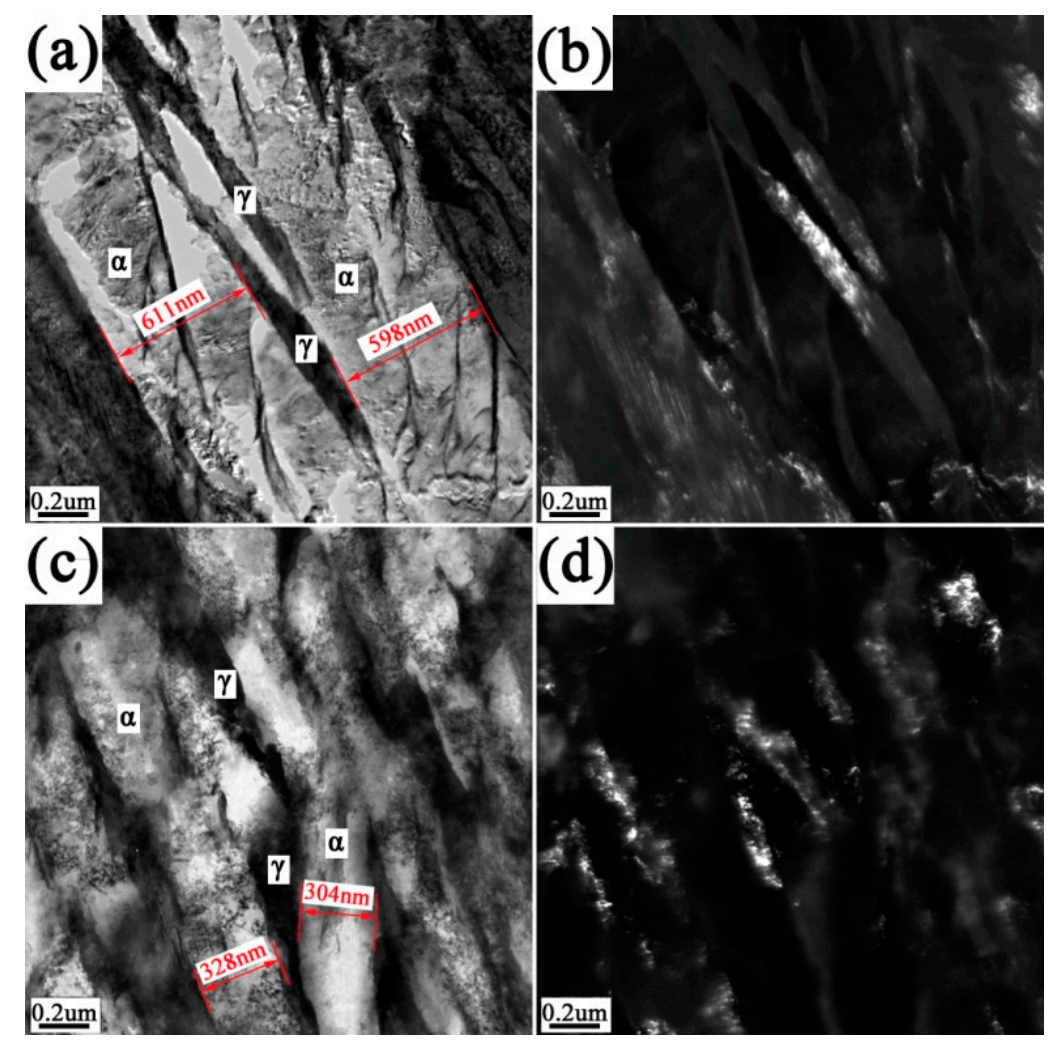

Figure 4. TEM investigations of samples at different conditions, $(\mathbf{a}, \mathbf{b})$ nondeformed sample isothermal transformed at $300{ }^{\circ} \mathrm{C} ;(\mathbf{c}, \mathbf{d})$ deformed with a strain of 0.3 followed by isothermal transformation at $300^{\circ} \mathrm{C}$. Blocky and film-like austenites are shown in dark (left) and bright (right) images, respectively.

\subsection{Kinetics of Bainitic Transformation}

To quantitatively characterize the amount of bainitic transformation in different ausforming conditions, the dilatation data were recorded by a laser dilatometer during the whole isothermal holding process. Figure 5 shows the normalized diameter change versus time, representing the varying amount of bainite during isothermal holding. The deformation process can complete itself within $0.3 \mathrm{~s}$ so that bainite reaction can be ignored during this very short time. The amount of bainite in the non-deformed sample transformed at $300{ }^{\circ} \mathrm{C}$ is much larger than that at $350{ }^{\circ} \mathrm{C}$ (Figure $5 \mathrm{a}$ ). When a strain of 0.1 is applied to the steel, there is still a gap between the volume fractions of bainite for two transformation temperatures, as shown in Figure 5b. However, the previous large distinction in the non-deformed condition is minimized by strain. With a continuous increase in ausforming strain, the difference in bainite amounts further decreases, which can be seen in Figure $5 c, d$. The results indicate that ausforming can partially compensate for the reduced bainite caused by a smaller undercooling.

The kinetics of bainitic transformation are analyzed using dilatometry and the results are presented in Figure 6. Without deformation, the rate of bainitic transformation in the sample tempered at $300{ }^{\circ} \mathrm{C}$ is higher than that at $350{ }^{\circ} \mathrm{C}$ (Figure 6a). The times for completing $90 \%$ transformation 
are $\sim 3200$ and $\sim 4400 \mathrm{~s}$, respectively. On the contrary, when a strain is applied, the kinetics of phase transition at $350{ }^{\circ} \mathrm{C}$ are much faster than that at $300{ }^{\circ} \mathrm{C}$, as shown in Figure $6 \mathrm{~b}-\mathrm{d}$. The bainitic transformation can almost finish within $\sim 1000 \mathrm{~s}$ at $350{ }^{\circ} \mathrm{C}$ and $\sim 2000 \mathrm{~s}$ at $300{ }^{\circ} \mathrm{C}$, which also can be proved by the horizontal lines in Figure 5. The results indicate that ausforming at a relative higher temperature is more favorable to the acceleration of isothermal bainitic transformation. In addition, compared with the non-deformed sample, the bainitic transformation in deformed austenite is greatly promoted by a prior strain.
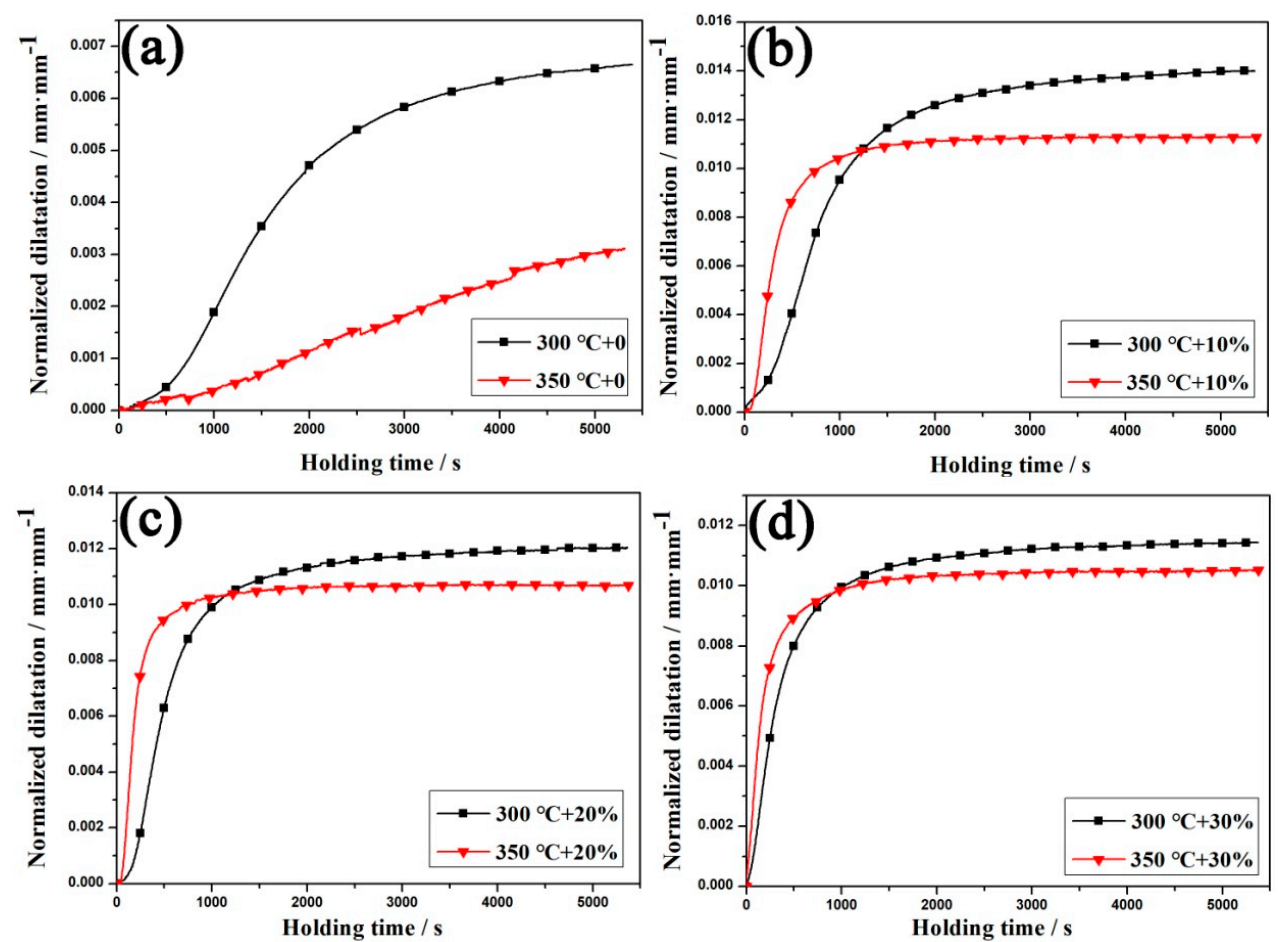

Figure 5. Normalized dilatation representing the amount of bainitic transformation during isothermal holding: (a) nondeformed samples; deformed with a strain of (b) 0.1 ; (c) 0.2 ; and (d) 0.3 .
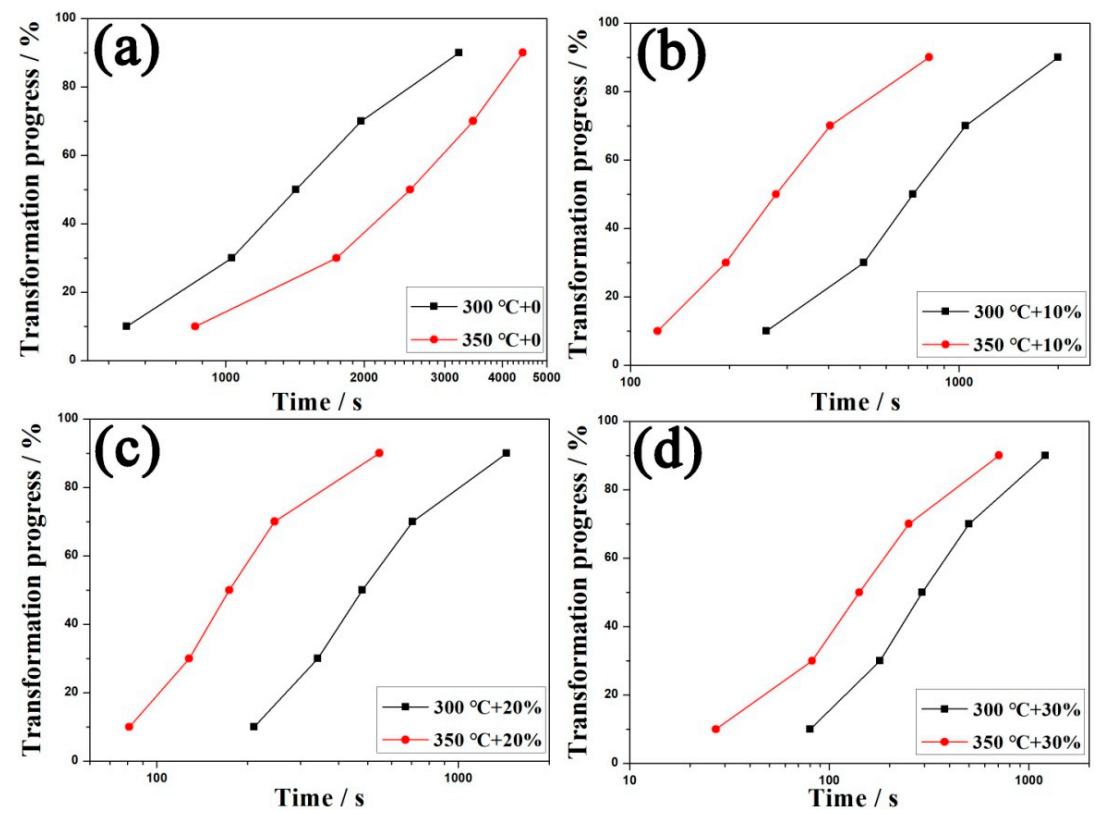

Figure 6. Bainite transformation kinetics in different samples measured using dilatometry: (a) nondeformed samples; deformed with a strain of (b) 0.1 ; (c) 0.2 ; (d) 0.3 . 


\section{Discussions}

In the present work, bainite plates can be significantly refined by ausforming at $300{ }^{\circ} \mathrm{C}$. The main factors influencing the thickness of bainite plate thickness include the strength of the austenite, the free energy change accompanying transformation and the transformation temperature. Singh et al. [27] reported that the thickness of bainite plates in silicon-rich steels reduces with the increase of the strength of the parent austenite at the transformation temperature. A large amount of dislocations induced by low temperature deformation were difficult to recover, resulting in the increase in strength of austenite. Therefore, the bainite plates in deformed austenite with a strain of 0.3 tend to be finer. In addition, the promoted nucleation due to deformation also contributes to refinement of the microstructure.

Both metallographical and dilatometric results manifest that the amount of bainitic transformation decreases with the increase of transformation temperature. The driving force for the transformation of austenite into bainite, $\Delta G^{\gamma \rightarrow \alpha}$, as well as the $T^{\prime}{ }_{0}$ curve of the test steel were calculated using the MUCG83 thermodynamic model $[25,26]$. The driving force for isothermal bainitic transformation increases with the decrease of temperature $\left(-1061 \mathrm{~J} \cdot \mathrm{mol}^{-1}\right.$ for $350{ }^{\circ} \mathrm{C},-1321 \mathrm{~J} \cdot \mathrm{mol}^{-1}$ for $\left.300{ }^{\circ} \mathrm{C}\right)$ (Figure 7a), leading to more bainite in the non-deformed austenite transformed at $300^{\circ} \mathrm{C}$ compared to that at $350{ }^{\circ} \mathrm{C}$. Bainitic formation are embedded in the concept of the $T^{\prime}{ }_{0}$ curve, which is the locus of points, on a temperature vs. carbon content plot, where austenite and ferrite of the same chemical composition have the same free energy, taking into account the stored energy of the ferrite due to the displacive mechanism of transformation $\left(400 \mathrm{~J} \cdot \mathrm{mol}^{-1}\right)$ [28]. It can be inferred from Figure $7 \mathrm{~b}$ that the residual austenite at $300{ }^{\circ} \mathrm{C}$ accommodates more carbon partitioned from newly formed bainite. Therefore, a bainitic reaction at a lower temperature could theoretically go further until the carbon concentration reaches the higher level. The kinetics of bainitic transformation can also be affected by alloying elements such as $\mathrm{Mn}$ and $\mathrm{Al}$. It was reported that that the transformation stasis phenomenon could occur in the Fe-C-Mn and Fe-C-Mn-Si alloys, while the transformation is approaching paraequilibrium mode with decreasing Mn concentration [29]. The Mn content of the tested steel $(2.8 \mathrm{wt}$. \%) is so high that the kinetics of bainitic transformation could also be retarded. In contrast, $\mathrm{Al}$ addition can be utilized to accelerate bainite formation due to the fact that it can increase the free energy change for transformation [4].
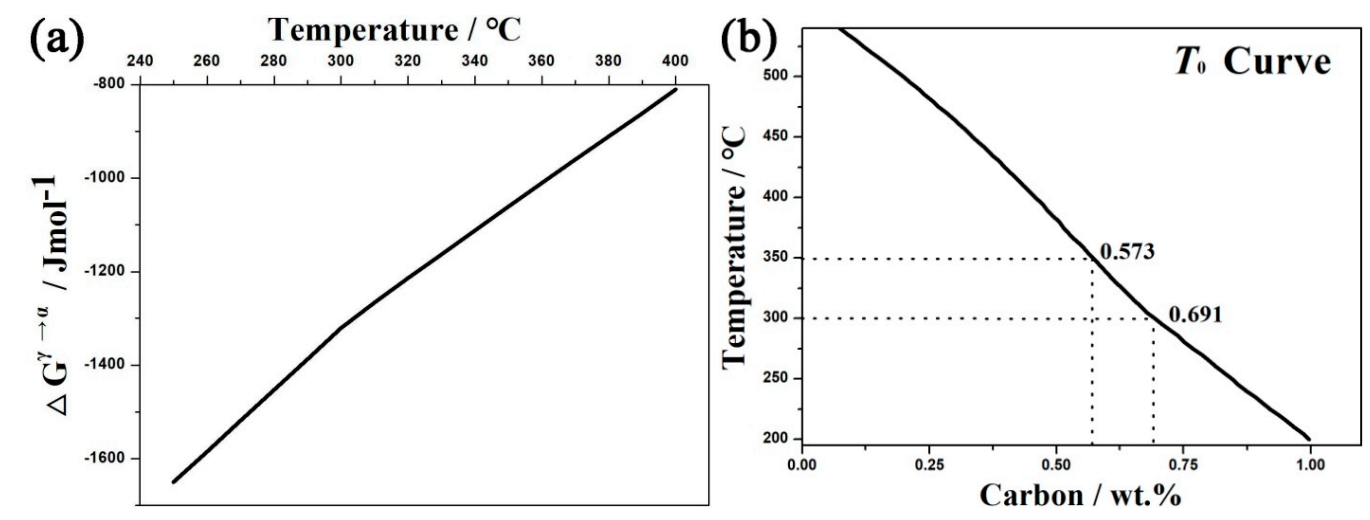

Figure 7. (a) The free energy change $\Delta G^{\gamma \rightarrow \alpha}$ as a function of temperature; (b) Calculated $T^{\prime}{ }_{0}$ curve of the tested steel.

It is worth noting that above situations does not exist after parent austenite is subjected to deformation. The difference of the amount of bainite formed by two tempering routes is characterized by the reduction of the dilatation amount, which can be calculated by equation: $\Delta D=D_{300}-D_{350}$, where $D_{300}$ and $D_{350}$ represent the amount of bainitic transformation in austenite transformed at 300 and $350{ }^{\circ} \mathrm{C}$, respectively. The rule of $\Delta D$ with the increase of strain is plotted in Figure 8 . It is clear that $\Delta D$ decreases with the increase of strain, indicating that ausforming can weaken the influence of 
undercooling on bainitic transformation. The larger the applied strain is, the less difference between the final amounts of bainite with different undercooling is.

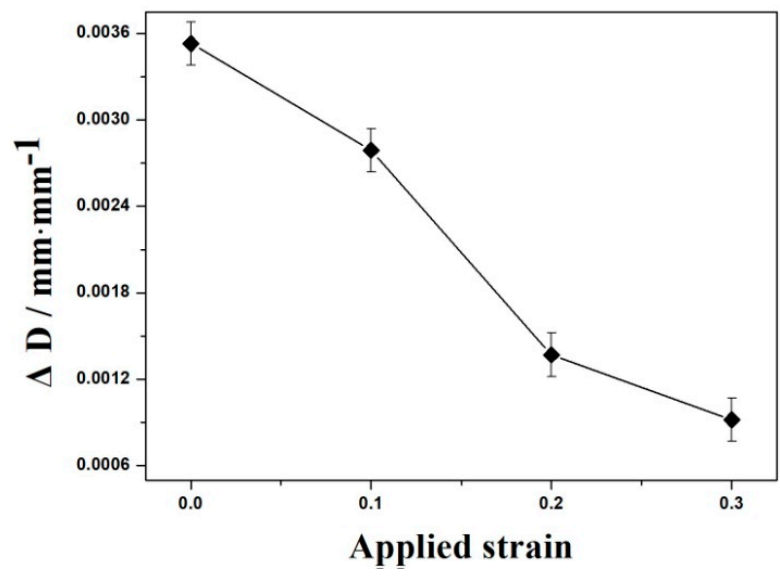

Figure 8. The changing tendency of $\Delta D$ with the strain.

For the bainitic transformation in ausformed austenite, kinetics is affected by both undercooling and distortion energy. The chemical driving force depends on composition and transformation temperatures, while deformation can provide mechanical driving force similar with the cases under stress [30]. In this way, the total driving force $\Delta G$ for isothermal bainitic transformation can be expressed by:

$$
\Delta G=G_{\text {Chem }}+G_{\text {Mech }}
$$

where $G_{C h e m}$ is chemical driving force for transformation, and $G_{\text {Mech }}$ is mechanical driving force. For the non-deformed sample, only $G_{\text {Chem }}$ should be taken into account because there is no mechanical driving force. However, after deformation, $G_{\text {Mech }}$ plays an important role in enhancing the nucleation rate of bainitic transformation [31,32]. Moreover, when the applied strain increases, the proportion of $G_{\text {Mech }}$ in the total driving force becomes larger, leading to the ratio of $G_{\mathrm{Mech}} / \Delta G$ approaching 1 . Therefore, the difference caused by undercooling is gradually receded due to strain. It should be noted that the applied stress for deformation was removed during the isothermal holding, which means that bainite forms without stress. Therefore, the $G_{\text {Mech }}$ in the bainitic transformation with prestrain is somewhat different to the case with stress. In the present work, the mechanical driving force for bainitic transformation may be related to two sides. One is that the stress field around dislocations can be locally created during straining, which may promote the formation of bainite. Secondly, it was reported that ausforming can lead to anisotropy of bainitic transformation [33], which is also known as variant selection [22]. Bainite formation with a favorable deformation texture can be promoted during the initial stage of isothermal holding. A kinetics model of bainitic transformation has been established considering the details of nucleation at the austenite grain surfaces and repeated nucleation of small platelets [34]. To better understand the kinetics of bainitic transformation with prestrain, further quantitative assessment on $G_{\text {Mech }}$ should be addressed in the future.

In addition, a certain strain of austenite can further accelerate the isothermal bainitic transformation at a relatively higher temperature. Figure 9 shows the transformation kinetics affected by ausforming with different strains. The solid line is for completing $10 \%$ of bainitic transformation, while the dashed line is for $90 \%$. Compared with the non-deformed case, the bainitic transformation regions with strains move to the left. Although the undercooling is decreased due to a higher transformation temperature, the rate of transformation at $350{ }^{\circ} \mathrm{C}$ is larger than at $300{ }^{\circ} \mathrm{C}$. Deformation can bring a large amount of nucleation sites at the initial stage of isothermal holding. In addition, the lengthening rate of bainite laths increases with the increase of transformation temperature [35]. This can be explained by the 
mechanism of carbon diffusion accompanying the bainitic transformation. Therefore, the kinetics of bainitic transformation in the initial stage can be accelerated by a higher ausforming temperature.

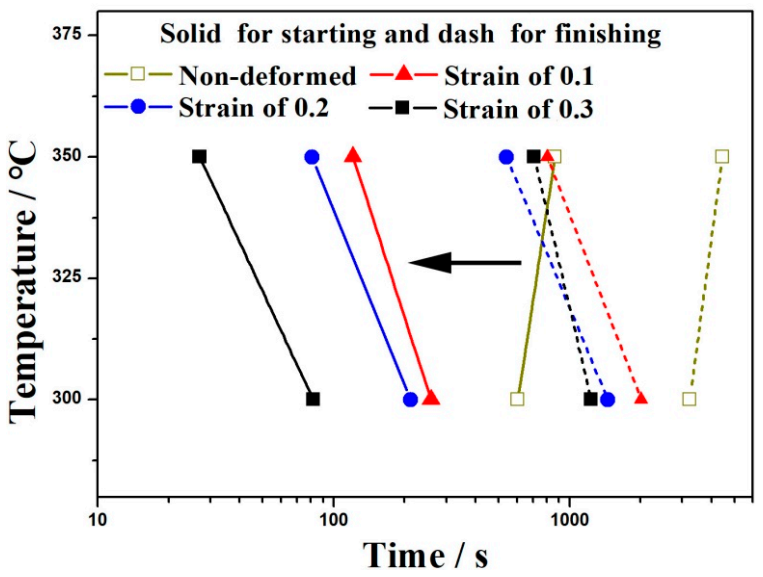

Figure 9. Effects of ausforming at 300 and $350{ }^{\circ} \mathrm{C}$ on kinetics of subsequent isothermal bainitic transformation.

It is generally considered that the martensite start temperature is decreased after plastic deformation of austenite. The large amount of dislocations generated by plastic deformation in austenite prior to the martensite transformation may stabilize the glissile embryo-austenite interface, leading to a decrease of $M s$. It was reported that Ms continuously decreased with the increase of the amount of deformation [36]. However, it is apparent that the effect of deformation on bainite formation is different from martensite. In our previous works $[19,20]$, we emphasized that a small strain at low temperatures can promote low-temperature bainitic transformation. After further investigation in the present work, slightly higher ausforming and transformation temperatures can be synchronously utilized with little distortion on the original positive efficiency. The results can provide reference for optimizing the production technology of MCBS.

\section{Conclusions}

The combined effects of ausforming and transformation temperature on bainitic transformation and microstructure were investigated by thermomechanical simulation and metallography. The results show that an ausforming with small strains can partially compensate for the reduced amount of bainite caused by a decreased undercooling. The difference between the final amounts of bainite at different undercoolings becomes smaller with the increase of strain. Ausforming at a higher temperature is more favorable to the acceleration of subsequent isothermal bainitic transformation. In the deformed austenite, the mechanical driving force plays an important role in determining the progress of isothermal bainitic transformation.

Author Contributions: H.H. and H.Z. conceived and designed the experiments; H.Z. performed the experiments; G.X. and F.D. analyzed the data; Z.X. contributed materials tools; H.H. wrote the paper.

Acknowledgments: The authors gratefully acknowledge the financial supports from the National Nature Science Foundation of China (Nos.51704217, 51874216), China Postdoctoral Science Foundation (2017M622533), the Major Projects of Technological Innovation in Hubei (No.2017AAA116), Hebei Joint Research Fund for Iron and Steel (E2018318013). The authors also thank Hatem Zurob at McMaster University, Canada for the suggestions and corrections on the present work.

Conflicts of Interest: The authors declare no conflict of interest. The founding sponsors had no role in the design of the study; in the collection, analyses, or interpretation of data; in the writing of the manuscript, and in the decision to publish the results. 


\section{Abbreviations}

The following abbreviations are used in this manuscript:

$\begin{array}{ll}\text { RA } & \text { retained austenite } \\ \text { MS } & \text { martensite starting temperature } \\ \text { MCBS } & \text { medium-carbon bainite steels } \\ \text { ICT } & \text { incomplete transformation } \\ \text { TTT } & \text { time-temperature-transformation } \\ \text { BS } & \text { bainite starting temperature } \\ \text { SEM } & \text { scanning electron microscopy } \\ \text { TEM } & \text { transmission electron microscope } \\ \text { B } & \text { bainite } \\ \text { M } & \text { martensite }\end{array}$

\section{References}

1. Caballero, F.G.; Bhadeshia, H.K.D.H.; Mawella, K.J.A.; Jones, D.G.; Brown, P. Very strong low temperature bainite. Mater. Sci. Technol. 2002, 18, 279-284. [CrossRef]

2. Caballero, F.G.; Bhadeshia, H.K.D.H. Very strong bainite. Curr. Opin. Solid State Mater. Sci. 2004, 8, $251-257$. [CrossRef]

3. Garcia-Mateo, C.; Caballero, F.G.; Bhadeshia, H.K.D.H. Mechanical properties of low-temperature bainite. Mater. Sci. Forum 2005, 500-501, 495-502. [CrossRef]

4. Garcia-Mateo, C.; Caballero, F.G.; Bhadeshia, H.K.D.H. Acceleration of low-temperature bainite. ISIJ Int. 2003, 43, 1821-1825. [CrossRef]

5. Yoozbashi, M.N.; Yazdani, S.; Wang, T.S. Design of a new nanostructured high-Si bainitic steel with lower cost production. Mater. Des. 2011, 32, 3248-3253. [CrossRef]

6. Yang, J.; Wang, T.S.; Zhang, B.; Zhang, F.C. Microstructure and mechanical properties of high-carbon Si-Al-rich steel by low-temperature austempering. Mater. Des. 2012, 35, 170-174. [CrossRef]

7. Yang, H.S.; Bhadeshia, H.K.D.H. Designing low carbon; low temperature bainite. Mater. Sci. Technol. 2008, 24, 335-342. [CrossRef]

8. Hu, H.J.; Xu, G.; Liu, F.; Wang, L.; Zhou, L.X.; Xue, Z.L. Dynamic observation of twin evolution during austenite grain growth in an Fe-C-Mn-Si alloy. Int. J. Mater. Res. 2014, 105, 337-341. [CrossRef]

9. Zhou, M.X.; Xu, G.; Wang, L.; Hu, H.J. Combined effect of the prior deformation and applied stress on the bainite transformation. Met. Mater. Int. 2016, 22, 956-961. [CrossRef]

10. Zhang, X.X.; Xu, G.; Wang, X.; Embury, D. Mechanical behavior of carbide-free medium carbon bainitic steels. Metall. Mater. Trans. A 2014, 45, 1352-1361. [CrossRef]

11. Zhang, M.; Wang, Y.H.; Zheng, C.L.; Zhang, F.C.; Wang, T.S. Effects of ausforming on isothermal bainite transformation behavior and microstructural refinement in medium-carbon Si-Al-rich alloy steel. Mater. Des. 2014, 62, 168-174. [CrossRef]

12. Zhou, M.X.; Xu, G.; Hu, H.J.; Yuan, Q.; Tian, J.Y. Comprehensive analysis on the effects of different stress states on the bainitic transformation. Mater. Sci. Eng. A 2017, 704, 427-433. [CrossRef]

13. Aaronson, H.I.; Reynolds, W.T.; Purdy, G.R. The incomplete transformation phenomenon in steel. Metall. Mater. Trans. A 2006, 37, 1731-1745. [CrossRef]

14. Bhadeshia, H.K.D.H.; Waugh, A.R. Bainite: An atom-probe study of the incomplete reaction phenomenon. Acta Metall. 1982, 30, 775-784. [CrossRef]

15. Xia, Y.; Miyamoto, G.; Yang, Z.G.; Zhang, C.; Furuhara, T. Direct measurement of carbon enrichment in the incomplete bainite transformation in Mo added low carbon steels. Acta Mater. 2015, 91, 10-18. [CrossRef]

16. Hasan, H.S.; Peet, M.J.; Avettand-Fènoël, M.-N.; Bhadeshia, H.K.D.H. Effect of tempering upon the tensile properties of a nanostructured bainitic steel. Mater. Sci. Eng. A 2014, 615, 340-347. [CrossRef]

17. Baradari, S.; Boutorabi, S.M. Effects of isothermal transformation conditions on the microstructure and hardness values of a high-carbon Al-Si alloyed steel. Mater. Des. 2015, 86, 603-609. [CrossRef]

18. Zhou, M.X.; Xu, G.; Wang, L.; Hu, H.J. Effect of undercooling and austenitic grain size on bainitic transformation in an Fe-C-Mn-Si superbainite steel. Trans. Indian Inst. Met. 2016, 69, 693-698. [CrossRef] 
19. Hu, H.J.; Zurob, H.S.; Xu, G.; Embury, D.; Purdy, G.R. New insights to the effects of ausforming on the bainitic transformation. Mater. Sci. Eng. A 2015, 626, 34-40. [CrossRef]

20. Hu, H.J.; Xu, G.; Zhou, M.X.; Yuan, Q. New insights to the promoted bainitic transformation in prior deformed austenite in a Fe-C-Mn-Si alloy. Met. Mater. Int. 2017, 23, 233-238. [CrossRef]

21. Gong, W.; Tomota, Y.; Koo, M.S.; Adachi, Y. Effect of ausforming on nanobainite steel. Scr. Mater. 2010, 63, 819-822. [CrossRef]

22. Gong, W.; Tomota, Y.; Adachi, Y.; Paradowska, A.M.; Kelleher, J.F.; Zhang, S.Y. Effects of ausforming temperature on bainite transformation; microstructure and variant selection in nanobainite steel. Acta Mater. 2013, 61, 4142-4154. [CrossRef]

23. Yang, Z.N.; Chu, C.H.; Jiang, F.; Qin, Y.M.; Long, X.Y.; Wang, S.L.; Chen, D.; Zhang, F.C. Accelerating nano-bainite transformation based on a new constructed microstructural predicting model. Mater. Sci. Eng. A 2019. [CrossRef]

24. He, B.B.; Xu, W.; Huang, M.X. Effect of ausforming temperature and strain on the bainitic transformation kinetics of a low carbon boron steel. Philos. Mag. 2015, 95, 1150-1163. [CrossRef]

25. Bhadeshia, H.K.D.H. A thermodynamic analysis of isothermal transformation diagrams. Met. Sci. 1982, 16, 159-165. [CrossRef]

26. Bhadeshia, H.K.D.H. Bainite in Steels; Institute of Materials: London, UK, 1992; pp. 1-450.

27. Singh, S.B.; Bhadeshia, H.K.D.H. Estimation of bainite plate-thickness in low-alloy steels. Mater. Sci. Eng. A 1998, 245, 72-79. [CrossRef]

28. Bhadeshia, H.K.D.H. Rationalisation of shear transformations in steels. Acta Metall. 1981, 29, 1117-1130. [CrossRef]

29. Chen, H.; van der Zwaag, S. The effect of interfacial element partitioning on ferrite and bainite formation. JOM 2016, 68, 1320-1328. [CrossRef]

30. Zhou, M.X.; Xu, G.; Zhang, Y.L. The effects of external compressive stress on the kinetics of low temperature bainitic transformation and microstructure in a superbainite steel. Int. J. Mater. Res. 2015, 106, 1040-1045. [CrossRef]

31. Hase, K.; Garcia-Mateo, C.; Bhadeshia, H.K.D.H. Bainite formation influenced by large stress. Mater. Sci. Technol. 2004, 20, 1499-1505. [CrossRef]

32. Zhou, M.X.; Xu, G.; Wang, L.; Yuan, Q. The varying effects of uniaxial compressive stress on the bainitic transformation under different austenitization temperatures. Metals 2016, 6, 119. [CrossRef]

33. Eres-Castellanos, A.; Morales-Rivas, L.A.; Latz, A.; Caballero, F.G.; Garcia-Mateo, C. Effect of ausforming on the anisotropy of low temperature bainitic transformation. Mater. Charact. 2018, 145, 371-380. [CrossRef]

34. Matsuda, H.; Bhadeshia, H.K.D.H. Kinetics of the bainite transformation. Proc. R. Soc. Lond. A 2004, 460, 1707-1722. [CrossRef]

35. Quidort, D.; Brechet, Y.J.M. Isothermal kinetics of bainite in 0.5\% C steels. Acta Mater. 2001, 49, 4161-4170. [CrossRef]

36. Shi, Z.M.; Li, J.; Chi, B.; Pu, J.; Zhang, Y.S.; Wang, M.Q.; Shi, J.; Dong, H. Martensitic phase transformation from non-isothermally deformed austenite in high strength steel 22SiMn2TiB. Metall. Mater. Trans. A 2013, 44, 4136-4142. [CrossRef]

(C) 2019 by the authors. Licensee MDPI, Basel, Switzerland. This article is an open access article distributed under the terms and conditions of the Creative Commons Attribution (CC BY) license (http://creativecommons.org/licenses/by/4.0/). 